\title{
OPTIMIZE THE DESCA POTENTIAL FOR NEW STUDENTS TO INCREASE THE SELF-CONCEPT IN THE COURSE GEOMETRY
}

\author{
Bistari \\ Department of Mathematics Education \\ Faculty of Education at the University of Tanjungpura Pontianak \\ bistari.bs@gmail.com
}

\begin{abstract}
The reasons of this research is to determine the results of a study about the ability of DESCA and self concept new students of Mathematics Education in the course geometry. The method which used in this research is descriptive analysis method. Subjects in this research are students of mathematics education 2014 which take a course of Geometry I in Faculty of Education at the University of Tanjungpura Pontianak. The results showed that among the five aspects of DESCA which gives a good change is the aspect of self-concept. So, it makes the increase of student's self-concept, such as the confidence to expression their ideas and the courage to self recognition and expression of self-concept in geometry classes. Other conditions which conducive to implementation is the correct or incorrect answer is not broken immediately, but for accommodated and analyzed together.
\end{abstract}

Keywords: DESCA, self concept, optimizing

Berdasarkan hasil pengamatan pada 38 mahasiswa angkatan tahun 2013 yang mengikuti perkuliahan Geometri 1 selama satu semester (Sepetember 2013 s.d Januari 2014) ditemukan bervariasi kondisi awal dan motivasi. Kajian dilakukan melalui pengamatan selama perkuliahan dan wawancara pada beberapa mahasiswa baru. Hasil analisis ditemukan beberapa hal yang terkait dengan potensi awal bidang matematika, motivasi kuliah, daya juang dalam menyelesaikan tugas, dan kepedulian dengan kondisi sekitar.

Pertama, terkait tentang potensi awal bidang matematika. Kemampuan awal bidang matematika merupakan salah satu syarat yang tak dapat ditawar, sebab potensi bidang matematika merupakan bekal utama dalam realisasi di lapangan untuk seorang guru matematika. Ternyata dari 38 mahasiswaterdiri dari 32 mahasiswa yang berlatarbelakang jurusan IPA dan 6 bukan dari jurusan IPA (SMK/IPS). Tentu bagi mahasiswa yang berasal bukan dari jurusan IPA memerlukan kerja lebih dari mahasiswa yang berasal dari jurusan IPA. Mahasiswa dari jurusan IPA belum menjamin konsep awal dalam posisi aman, karena ditemukan berdasarkan hasil tes awal bahwa dari 32 mahasiswa tersebut ternyata yang berada pada standar memadai hanya 18 orang.

Kedua, tentang motivasi kuliah. Ternyata $67 \%$ mahasiswa baru masuk di prodi pendidikan matematika atas keinginan sendiri tentunya dengan berbagai alasan, tetapi ada 
23\% mahasiswa baru yang masuk prodi pendidikan matematika karena bukan dari dirinya, seperti keinginan orang tua, anjuran guru dan ikut-ikutan teman. Apapun motivasinya, harus diasah kembali sehingga muncul kesadaran terhadap kebutuhan. Bahwa dalam proses perkuliahan yang diharapkan adanya muncul kesadaran diri bahwa yang butuh adalah diri sendiri-sendiri. Sikap ini perlu ditanamkan sejak dini (saat mahasiswa baru), sehingga terbiasa pada tantangan dan menjadi permanen yang positif.

Ketiga, daya juang dalam penyelesaian tugas lemah. Gejala ini terungkap dari cara mahasiswa baru merespon dan menyelesaikan tugastugas tersebut. Merespon tugas yang diberikan bahwa mereka tidak antusias dalam penitipan soal-soal tugas. Pada menyelesaikan tugas kurang bervariasi, karena mereka bersumber hanya dari beberapa orang, melalui pendekatan DESCA ada 5 fokus potensi mahasiswa yang dapat dikembangkan dan dioptimalkan, yakni dignity (martabat), energy(energi), self management (manajemen diri), community (komunitas), dan awareness (kepedulian). Semua mahasiswa memiliki kemampuan bawaan untuk hidup dan bekerja penuh harga diri, begitu juga dengan kita semua. Pengajar perlu memberikan inspirasi kepada para mahasiswa agar secara utuh menjadi pembelajar yang aktif. Ini salah satu martabat pembelajar yang perlu dikembangkan, sehingga setiap mahasiswa belajar tidak dalam tekanan dan tidak dipermalukan.Energi yang dimaksudkan disini yaitu penggunaan secara efektif dalam memperoleh pemahaman konsep. Misal dengan bekerja dalam kelompok, belajar secara riang seperti sambil bernyanyi.
Manajemen diri dapat dilakukan melalui memasukkan beberapa pilihan dalam tugas rumah mahasiswa, biarkan mahasiswa memilih temannya sendiri dalam pembentukan kelompok atau diskusi kecil, serta membuat rencana pribadi.

Salah satu potensi mahasiswa yang akan digali dalam penelitian ini adalah konsep diri (self concept). Bagi mahasiswa yang masih mencari jati diri pada saat menginjakkan kaki di kampus perlu penguatan dan pembentukan sehingga jati diri sebagai mahasiswa dapat diperoleh. Muara dari semua itu adalah percaya diri. Untuk mahasiswa yang telah memiliki percaya diri maka memiliki kemungkinan untuk penyelesaian tugas dan studi secara mandiri. Sehingga kemandirian inilah yang salah benteng utama ketika tugas di lapangan.

Agar terarah dalam pencapaian kerja dan kegiatan penelitian, maka penelitian ini bertujuan sebagai berikut.Pertama, mengetahui hasil kajian tentang posisi tangga pembelajaran aktif mahasiswa baru baru Prodi Pendidikan Matematika perkuliahan geometri sebelum pengoptimalan kemamapuan $D E S C A$.Kedua, menggali informasi tentang kemampuan DESCA mahasiswa baru Prodi Pendidikan Matematika perkuliahan geometri pada pertemuan ke 2 dan ke 3.Ketiga, menggali informasi tentang self concept mahasiswa baru Prodi Pendidikan Matematika perkuliahan geometri pada pertemuan ke 2 dan ke 3. Keempat, mengetahui hasil kajian tentang apa saja perubahan dan penyebabnya terkait kemampuan DESCA dan self concept mahasiswa baru Prodi Pendidikan Matematika selama perkuliahan geometri. 
Konsep diri merupakan terjemahan dari self concept dan menurut Fuhrman (1990:340) konsep diri adalah konsep dasar tentang diri sendiri, pikiran dan opini pribadi, kesadaran tentang apa dan siapa dirinya dan bagaimana perbandingan antara dirinya dengan orang lain serta bagaimana idealism yang telah dikembangkannya. Hal ini sejalan dengan pandangan Calhaoun dan Acocella (Ghufron dan Rini, 2011:13) yang menyatakan bahwa konsep diri merupakan gambaran mental diri seseorang. Self concept atau konsep diri adalah semua ide-ide, pikiran, kepercayaan, dan pendirian yang diketahui individu tentang dirinya dan mempengaruhi individu dalam berhubungan dengan orang lain. Self concept memiliki sifat multi dimensi yang beberapa diantaranya lebih terkait dengan aspek kepribadian tertentu (fisik, sosial, emosional), sementara yang lain lebih terkait dengan prestasi akademik.

$$
\text { Self Concept merupakan }
$$

gambaran yang dimiliki seseorang mengenai diri sendiri, yang dibentuk melalui proses pengalamanpengalaman yang diperoleh dari interaksi terhadap lingkungan. Self Concept bukan merupakan faktor bawaan, melainkan berkembang dari pengalaman yang terus menerus dan terdiferensiasi. Hal ini sejalan dengan pendapat William H. Fitts (Agustiani, 2006:138-139) bahwa konsep diri (self concept) merupakan satu aspek penting dalam diri seseorang, karena konsep diri seseorang merupakan kerangka acuan (frame of reference) dalam melakukan interaksi dengan lingkungan.

Berdasarkan teori yang sudah dijelaskan sebelumnya tentang pengertian self concept, maka dapat disimpulkan pengertian self concept adalah penilaian seseorang terhadap dirinya sendiri mengenai keyakinan fisik, psikologis, sosial dan prestasi. Dalam penelitian ini, self concept adalah penilaianmahasiswa terhadap dirinya dan kemampuan dalam bidang matematika yang dimilikinya.

Tabel 1.Skor Tingakatan Self concept.

\begin{tabular}{cc}
\hline Tingkatan Self Concept & Skor ( \% ) \\
\hline Tinggi & $56-90$ \\
\hline Sedang & $36-55$ \\
\hline Rendah & $0-35$ \\
\hline
\end{tabular}

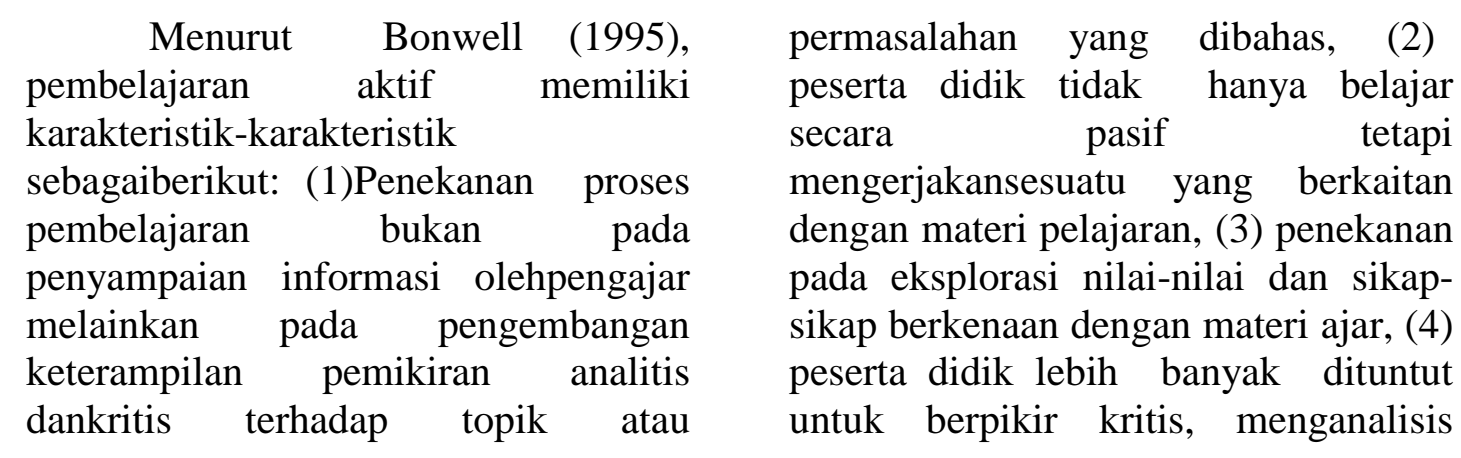


danmelakukan evaluasi, dan (5) umpan-balik yang lebih cepat akan terjadi pada proses pembelajaran.

Tangga pembelajaran aktif merupakan tingkatan keaktifan peserta didik didasari oleh tanggungjawab dalam pembelajaran. Ada 4 tingkatan dalam tangga pembelajaran aktif, yakni:Tingkat 1: Mahasiswa yang sepenuhnya aktif. Tingkat 2:Mahasiswa yang bertanggung jawab.Tingkat 3: Mahasiswa belajar dengan setengah hati.Tingkat 4: Mahasiswa yang menghindari belajar.Dalam penelitian ini mengupayakan pembelajaran aktif, dengan acuan pada pendekatan DESCA. Kemajuan pembelajaran yang diperlihatkan mahasiswa juga dilihat dari tangga pembelajaran aktif. Melalui pengembangan dan pengoptimalan pada potensi DESCAyang dimiliki mahasiswa, diharapkan memiliki keterkaitan dengan self concept-nya.

Dalam proses perkuliahan, keempat potensi DESCA diupayakan dan dikondisikan terjadi, untuk mengetahui kemajuan dan tingkat keberhasilan kelas digunakan lembar pengamatan pendekatan DESCA(skala $D E S C A$ ), sedangkan untuk mengetahui tingkat kemampuan yang dimiliki mahasiswa digunakan lembar kuesioner DESCA. Terkait dengan level self concept dapatditelusuri melalui angket self concept.

\section{Metode}

Penelitian ini menggunakan metode deskriptif analisis. Metode deskriptif analisis adalah prosedur untuk menggambarkan subyek/obyek penelitian pada saat sekarang berdasarkan fakta-fakta yang tampak atau sebagaimana adanya. Kemudian dari fakta tersebut dicari pemecahannya dengan memberikan suatu perlakuan
(Sulipan, 2009).Berdasarkan pendapat tersebut, maka didalam penelitian ini fakta-fakta hasil pengamatan, lembar kuesioner dan hasil tes yang tertuang pada lembar jawaban mahasiswa dan hasil wawancara.Subjek dalam penelitian ini adalah mahasiswa pendidikan matematika angkatan 2014 yang mengikuti matakuliah Geometri I di FKIP UNTAN Pontianak. Peneliti memilih kelas tersebut dikarenakan kelas tersebut tergolong kelas khusus yang perlu pembinaan juga secara khusus.

Prosedur yang dilakukan yakni memberikan angket self-conceptpada mahasiswa, melakukan pengembangan pada kompetensi DESCA yang dimiliki mahasiswa melalaui keterkaitan RPP yang mengarah ke DESCA, lembar pengamatan DESCA, lembar observasi $D E S C A$, dan kemajuan prestasi mahasiswa (tugas \&tes). Selanjutnya memberikan angket self-confidence kepada mahasiswa. Pada tahap akhir, mendeskripsikan hasil penelitian, menganalisis data dan membuat kesimpulan.Alat pengumpul data yang digunakan dalam penelitian ini adalah sebagai berikut:Angket SelfConceptdan angket DESCA.Dalam penelitian ini angket yang digunakan adalah angket tertutup. Angket ini tidak memerlukan alasan dari responden/mahasiswa. Angket ini digunakan untuk mengukur seberapa tinggi self-concept mahasiswa sebelum dan setelah melalui pembelajaran pendekatan DESCA dalam perkuliahan geometri.

\section{Hasil dan Pembahasan}

Hasil penelitian diperoleh dari pengumpul data dengan cara: (1) observasi, (2) angket, (3) dokumentasi, dan (4) wawancara. Setelah data 
diperoleh berikutnya dilakukan analisis dengan cara memilah data tersebut untuk dikelompokkan pada pertanyaan penelitian yang relevan. Analisis dilakukan dengan memperhatikan data kuantitatif yang dideskripsikan ke arah kualitatif, sedangkan pada bagian pembahasan penelitian yang dikaji adalah hasil temuan yang dianggap memberikan kondisi kondusif maupun yang menghambat. Posisi Tangga Pembelajaran Aktif Mahasiswa Baru Prodi Pendidikan Matematika Perkuliahan Geometri Sebelum
Pengoptimalan Kemamapuan DESCA.Tangga pembelajaran aktif merupakan tingkatan keaktifan peserta didik didasari oleh tanggungjawab dalam pembelajaran. Ada 4 tingkatan dalam tangga pembelajaran aktif, yakni:(1) Mahasiswa yang sepenuhnya aktif, (2) Mahasiswa yang bertanggung jawab, (3) Mahasiswa belajar dengan setengah hati, dan (4) Mahasiswa yang menghindari belajar.Berdasarkan hasil observasi dari 2 orang pengamat diperoleh data berikut.

Tabel 2. Rekap Tangga Pembelajaran Aktif.

\begin{tabular}{llccc}
\hline No & Kondisi Mahasiswa dalam Perkulihan & $\begin{array}{c}\text { Kegiatan } \\
\text { Awal }\end{array}$ & $\begin{array}{c}\text { Kegiatan } \\
\text { Inti }\end{array}$ & $\begin{array}{c}\text { Kegiatan } \\
\text { Penutup }\end{array}$ \\
\hline 1. & Mahasiswa yang sepenuhnya aktif & 6 & 8 & 3 \\
\hline 2. & Mahasiswa yang bertanggung jawab. & 19 & 21 & 20 \\
\hline 3. & Mahasiswa belajar dengan setengah hati & 4 & 2 & 7 \\
\hline 4. & Mahasiswa yang menghindari belajar & 2 & 0 & 1 \\
\hline \multicolumn{5}{r}{ Catatan:Jumlah mahasiswa yang hadir dalam perkuliahan 31 orang. }
\end{tabular}

\section{Kemampuan DESCA}

Kemampuan DESCA Mahasiswa Baru Prodi Pendidikan Matematika pada Perkuliahan Geometri Berdasarkan hasi observasi pada penanya saya sangat

a. Kegiatan Awal

1) $85 \%$ dari seluruh mahasiswa memperhatikan informasi awal yang disampaikan pengajar berkaiatan dengan perkuliahan geometri 1

$\begin{array}{lr}2) \quad \text { orang mahasiswa } \\ \text { mempertanyakan } & \text { tentang } \\ \text { kejelasan } & \text { materi. }\end{array}$ Pertanyaannya sebagai berikut:

a) Saya kurang aktif jika di suruh ke depan kelas atau dalam diskusi kelompok. Saya mengalami kesulitan untuk menyampaikan/menjelaska n kepada teman. Sebenarnya saya sangat observasi pada pertemuanttertama ${ }^{2}$ diperoleh data tentang pen teman lainnya, tetapi saya binggung bagaimana katakata yang sopan dan mudah di pahami orang lain?

b) Ketika saya pertama masuk kuliah merasa bosan, dan pada akhir perkuliahan saya baru merasakan keenakan dalam kuliah. Bagaimana caranya agar saya merasa senang pada saat di awal perkuliahan?

c) Persamaan parameter itu digunakan untuk menggambar gariskah ? 
d) Persamaan parameter biasa digunakan untuk apa?

e) $\mathrm{t}$ dalam persamaan parameter melambangkan apa ?

3) $60 \%$ dari seluruh mahasiswa berani bercerita tentang pembelajaran yang sebelumnya.

b. Kegiatan Inti

1) $74 \%$ dari seluruh mahasiswa menyelesaikan soal yang diberikan pengajar dengan sepenuh hati.

2) $70 \%$ dari seluruh mahasiswa menyelesaikan soal yang diberikan pengajar dengan bertanggung jawab.

3) $30 \%$ dari seluruh mahasiswa menyelesaikan soal yang diberikan pengajar dengan setengah hati.

4) $74 \%$ dari seluruh mahasiswa yang tetap fokus dalam diskusi.

5) $35 \%$ dari seluruh mahasiswa mendapat hukuman yang mendidik.

6) $75 \%$ dari seluruh mahasiswa dapat mengajarkan pada temannya dengan serius.

7) $75 \%$ terjadi aktivitas/gerakan dalam proses pembelajaran.

8) $30 \%$ mahasiswa yang mendapat teguran agar suasana menjadi kondusif.

9) $70 \%$ dari seluruh mahasiswa saling berbagi bersama temannya.

c. Kegiatan Penutup

a. $75 \%$ dari seluruh mahasiswa merespon materi yang telah disampaikan. b. 2 orang mahasiswa menanggapi tentang perkuliahan yang telah disampaikan. Berikut tanggapan mereka:

Selama proses pembelajaran seru dan tidak membuat mengantuk. Mahasiswa dilibatkan dalam pembelajaran dan karena geometri perlu dijelaskan menggunakan bahasa Indonesia, jadi kami lebih mudah mengerti daripada menggunakan bahasa inggris.

\section{Posisi Tangga Pembelajaran Aktif}

Berdasarkan Tabel 2 sebelumnya, dapat diuraikan terkait dengan aktivitas mahasiswa sebagai berikut:

a. Mahasiswa yang Sepenuhnya Aktif

Mahasiswa yang sepenuhnya aktif dalam perkuliahan terlihat dari beberapa gejala berikut. Pertama, siap dan mau menyelesaikan tugastugas perkuliahan. Kedua, melakukan pekerjaan dengan ciri khas tersendiri. Ketiga, lengkap dan rapi dalam menyelesaikan tugas. Keempat, memiliki keuletan dan sifat pantang menyerah. Siap dan mau menyelesaikan tugas-tugas perkuliahan ini dapat terdeteksi dari tugas-tugas yang dikerjakan mahasiswa. Tugas yang diamati yakni tugas rumah, tugas kampus kelompok, dan tugas kampus individu. Terkait tugas rumah mahasiswa sebagian besar $(80 \%)$ mengumpulkan secara lengkap dan rapi. Namun ada 13\% (4 mahasiswa) tugas yang dikumpulkan tak lengkap dan pekerjaan tergolong rapi. Sedangkan 7\% (2 mahasiswa) tugas dikerjakan dalam kondisi darurat.Dari 80\% (24 mahasiswa) 
menggunakan peralatan yang valid (penggaris, jangka, kertas berpetak). Bila diamati dalam proses perkuliahan, ada 5mahasiswa tersebut tergolong aktif dalam bertanya dan memiliki perhatian yang penuh mulai awal perkuliahan sampai dengan akhir perkuliahan. Ini berarti, 5 mahasiswa tersebut dapat dikelompokkan dalam tangga belajar mahasiswa yang sepenuhnya aktif.

b. Mahasiswa yang

Bertanggungjawab

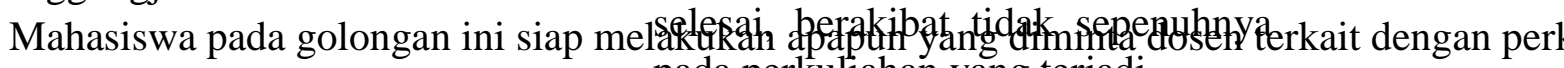
melakukan kontribusi positif dalam pembelajaran. Sesungguhnya mahasiswa seperti ini lebih mudah

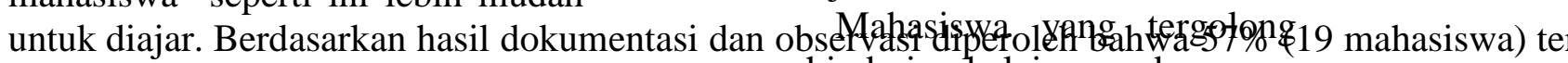
pada mahasiswa yang bertanggungjawab. Jika mahasiswa berada pada kelompok ini, maka dalam perkuliahan akan memberikan hal-hal yang kondusif sehingga perkuliahan dapat berjalan secara efektif. Namun masih dipertanyakan untuk mencapai hasil yang optimal, karena hasil perkuliahan juga dipengaruhi oleh kesiapan psikis maupun fisik peserta didik.

c. Mahasiswa yang Belajar dengan Setengah Hati

Dalam perkuliahan tidak dapat dihindari kondisi mahasiswa yang belajar dengan setengah hati. Dalam penyelesaian tugas yang dibebankan mahasiswa golongan ini mengerjakan tugas tersebut dengan asal-asalan, sehingga muncul kesalahan yang tidak perlu. Lambat untuk memulai pembelajaran, dan sifatnya cepat menyerah. Jika diajar dapat membuat frustasi bagi pengajar. Berdasarkan dokumentasi dan observasi diperoleh data bahwa $10 \%$ (3 mahasiswa) tergolong belajar dengan setengah hati. Hasil ini dari rata-rata 2 kali observasi dalam perkuliahan dan 2 kali tugas rumah yang dikumpulkan, sedangkan mahasiswa yang dimaksud 2 diantaranya berbeda. Hasil wawancara terungkap bahwa 2 dari 3 mahasiswa pada pengamatan pertama menyatakan bahwa pada perkuliahan tersebut ia masih memikirkan tentang tugas dan laporan praktikum yang belum pada perkuliahan yang terjadi.

d. Mahasiswa yang menghindari belajar

menghindari belajar sebenarnya tidak ada satupun, namun ada satu mahasiswa yang dapat dikatakan mendekati sikap mahasiswa yang ingin menghindar. Gejala ini tampak dari cara menyelesaikan tugas yang tidak memperhatikam keteraturan sama sekali. Tugas yang dikumpul sangat jauh dari prosedur semestinya. Tidak disiplin dalam pengumpulan tugas. Dari raut wajah dan tatapan mata dalam mengikuti perkuliahan tergolong "kosong". Tidak memiliki keinginan dan kegairahan dalam perkuliahan. Ketika diberikan tugas cenderung memiliki ketergantungan dengan teman.Saat menghadapi perkuliahan dan menyimak penjelasan dosen, tatapan mata dan cara pandang tergolong tak memiliki ketertarikan sama sekali. Hal yang menguntungkan ternyata mahasiswa pada golongan ini tak banyak. Kondisi seperti ini disebabkan karena sebagian besar mahasiswa 
yang lulus setelah melalui kompetisi yang ketat.

3. Kemampuan DESCA Mahasiswa Baru

Berdasarkan uraian hasil observasi diatas, diperoleh bahwa sebanyak $70 \%$ dari seluruh mahasiswa yang sepenuhnya aktif dan bertanggung jawab ketika diberikan tugas atau pertanyaan pada perkuliahan geometri.Dan $30 \%$ dari seluruh mahasiswa yang belajar atau mengikuti perkuliahan dengan sepenuh hati. Hal ini dilihat pada saat diberikan tugas atau pertanyaan tentang perkuliahan geometri, mereka tidak mengerjakannya dengan bersungguhsungguh. Selain itu, pada saat penjelasan materi, mereka tidak fokus mendengarkan atau sibuk sendiri.

Berdasarkan hasil data angket DESCA dan angket self concept, diperoleh data dari 31 mahasiswa prodi Pendidikan Matematika sebagai berikut: rata-rata angket DESCA 3,56. Dan deskripsi hasil angket DESCA dari 31 mahasiswa diperoleh data pada aspek dignity (martabat) sebagai berikut: $83 \%$ dari seluruh mahasiswa senang dan bangga dengan diri mereka. $81 \%$ mahasiswa cukup positif dan yakin pada kemampuan mereka.62\% mahasiswa tidak yakin terhadap perasaan mereka. $77 \%$ mahasiswa tidak merasa senang dengan diri mereka sendiri,dan $\quad 74 \%$ mahasiswa beranggapan bahwa mereka tidak pantas, tidak berdaya dan lemah dalam pemahaman geometri.

Aspek energy (energi) diperoleh data sebagai berikut: $66 \%$ mahasiswa aktif dalam mata kuliah geometri. $74 \%$ mahasiswa memiliki energy sepanjang waktu perkuliahan geometri.57\% mahasiswa tidak yakin pada perasaan mereka.68\% mahasiswa tidak terlalu mencurahkan energi dalam perkuliahan.63\% mahasiswa pasif dalam perkuliahan, dan $72 \%$ mahasiswa gelisah dalam perkuliahan.

Aspek self management (manajemen diri) diperoleh data sebagai berikut: $73 \%$ mahasiswa membuat banyak pilihan untuk diri sendiri.81\% mahasiswa selalu merasa bertanggung jawab atas diri sendiri.72\% mahasiswa merasa sedikit melakukan manajemen diri. 60\% mahasiswa tidak yakin dengan apa yang mereka rasakan. $71 \%$ mahasiswa mengikuti arus, tidak terlalu mengandalkan diri, dan $77 \%$ mahasiswa, setiap tugas yang dibebankan pada mereka, tidak pernah mereka lakukan dengan rasa tanggung jawab.

Aspek community (komunitas) diperoleh data sebagai berikut: $84 \%$ mahasiswa merasa bagian dari kelompok. $83 \%$ mahasiswa selalu siap membantu anggota kelompok.85\% mahasiswa merasa teman-teman bersikap baik pada mereka.63\% mahasiswa tidak yakin dengan perasaan mereka ketika berada dalam kelompok. $71 \%$ mahasiswa tidak merasa diterima secara penuh oleh teman-teman lain. $81 \%$ mahasiswa tidak terlalu berkeinginan untuk membantu temanteman dalam menyelesaikan tugas atau permasalahan,dan $70 \%$ mahasiswa merasa keegoisan dan penolakan dari teman lain.

Aspek awareness (wawasan) diperoleh data sebagai berikut: $65 \%$ mahasiswa berwawasan dan siap sepanjang waktu. 69\% mahasiswa merasa wawasan dan siap sepanjang waktu. 59\% mahasiswa tidak yakin 
dengan pesaan mereka. 57\% mahasiswa sering kali merasa tidak tertarik atau bosan,dan $65 \%$ mahasiswa hanya sedikit memperhatikan.

Hasil angket self concept, sebanyak 19 mahasiswa mempunyai self concept yang tinggi dan 12 mahasiswa mempunyai self concept yang sedang. Deskripsi hasil angket self concept mahasiswa sebagai berikut: $52 \%$ mahasiswa mampu memecahkan masalah di soal-soal geometri diluar contoh yang ada. 66\% mahasiswa kesulitan dalam memecahkan masalah di soal-soal geometri, mereka tetap berusaha menyelesaikannya sendiri sambil memperlajari kembali.68\% mahasiswa bersedia membantu teman atau saudara mereka dalam memecahkan masalah di soal geometri.41\% mahasiswa selalu meminta bantuan teman atau saudaranya dalam memecahkan masalah disoal geomteri.59\% mahasiswa, tugas geometri yang mereka kerjakan selalu dikumpulkan tanpa ada niat untuk memperbaiki jika ada kesalahan.50\% mahasiswa selalu dapat memecahkan masalah di soal-soal geometri dengan baik.60\% mahasiswa menyukai mata kuliah geometri.59\% mahasiswa tidak suka bila mendapat tugas geometri. 57\% mahasiswa bisa menyelesaikan tugas geometri tergantung pada teman,dan $44 \%$ mahasiswa mampu mengerjakan soalsoal geometri di atas 5 jam.

4. Self-concept Mahasiswa Baru Prodi

Pendidikan Matematika Perkuliahan

Geometri pada Pertemuan ke 2 dan ke 3.

Pengisian angket tentang Self-Concept mahasiswa baru Prodi Pendidikan Matematika dilakukan pada saat perkuliahan 2 dan 3. Pengisian pertama dilakukan pada saat awal perkuliahan geometri pada pertemuan ke-2, sedangkan pengisian angket kedua dilakukan pada perkuliahan geometri pada akhir pertemuan ke 3 .

Tabel 3 memberikan gambaran bahwa tentang jawaban 31 mahasiswa yang dikaji dari setiap item. Banyak item yang dikaji yakni 20 item. Ratarata yang diberoleh dari 20 item tersebut ternyata ada rata-rata item yang memberikan kenaikan, penurunan dan tetap. Kenaikan ini dapat disebabkan beberapa hal, seperti perubahan kesiapan mahasiswa, penyesuaian dalam iklim perkuliahan dan rasa keyakinan.

Berdasarkan hasil data angket DESCA dan angket self concept pada pertemuan kedua (setelah dilakukan penedekatan DESCA), diperoleh data dari 31 mahasiswa prodi Pendidikan Matematika sebagai berikut: rata-rata angket DESCA 3,72. Dan deskripsi hasil angket DESCA dari 31 mahasiswa diperoleh data pada aspek dignity (martabat) sebagai berikut: $83 \%$ dari seluruh mahasiswa senang dan bangga dengan diri mereka. $80 \%$ mahasiswa cukup positif dan yakin pada kemampuan mereka.72\% mahasiswa tidak yakin terhadap perasaan mereka.86\% mahasiswa tidak merasa senang dengan diri mereka sendiri,dan 85\% mahasiswa beranggapan bahwa mereka tidak pantas, tidak berdaya dan lemah dalam pemahaman geometri.

Aspek energy (energi) diperoleh data sebagai berikut: $65 \%$ mahasiswa aktif dalam mata kuliah geometri. $72 \%$ mahasiswa memiliki energy sepanjang waktu perkuliahan geometri.66\% mahasiswa tidak yakin pada perasaan mereka.72\% mahasiswa tidak terlalu mencurahkan energi dalam 
perkuliahan.67\% mahasiswa pasif dalam perkuliahan, dan $74 \%$ mahasiswa gelisah dalam perkuliahan.

Aspek self management (manajemen diri) diperoleh data sebagai berikut: $76 \%$ mahasiswa membuat banyak pilihan untuk diri sendiri.79\% mahasiswa selalu merasa bertanggung jawab atas diri sendiri.61\% mahasiswa merasa sedikit melakukan manajemen diri. $64 \%$ mahasiswa tidak yakin dengan apa yang mereka rasakan. $72 \%$ mahasiswa mengikuti arus, tidak terlalu mengandalkan diri,dan $82 \%$ mahasiswa, setiap tugas yang dibebankan pada mereka, tidak pernah mereka lakukan dengan rasa tanggung jawab.

Aspek community (komunitas) diperoleh data sebagai berikut: 85\% mahasiswa merasa bagian dari kelompok. 85\% mahasiswa selalu siap membantu anggota kelompok.85\% mahasiswa merasa teman-teman bersikap baik pada mereka.84\% mahasiswa tidak yakin dengan perasaan mereka ketika berada dalam kelompok. $76 \%$ mahasiswa tidak merasa diterima secara penuh oleh teman-teman lain. $85 \%$ mahasiswa tidak terlalu berkeinginan untuk membantu temanteman dalam menyelesaikan tugas atau permasalahan, dan $77 \%$ mahasiswa merasa keegoisan dan penolakan dari teman lain.

Aspek awareness (wawasan) diperoleh data sebagai berikut: $64 \%$ mahasiswa berwawasan dan siap sepanjang waktu. 68\% mahasiswa merasa wawasan dan siap sepanjang waktu. 65\% mahasiswa tidak yakin dengan pesaan mereka. $64 \%$ mahasiswa sering kali merasa tidak tertarik atau bosan, dan $76 \%$ mahasiswa hanya sedikit memperhatikan.

Hasil angket self concept, sebanyak 23 mahasiswa mempunyai self concept yang tinggi dan 8 mahasiswa mempunyai self concept yang sedang. Deskripsi hasil angket self concept mahasiswa sebagai berikut: 54\% mahasiswa mampu memecahkan masalah di soal-soal geometri diluar contoh yang ada. 66\% mahasiswa kesulitan dalam memecahkan masalah di soal-soal geometri, mereka tetap berusaha menyelesaikannya sendiri sambil memperlajari kembali. $67 \%$ mahasiswa bersedia membantu teman atau saudara mereka dalam memecahkan masalah di soal geometri. $43 \%$ mahasiswa selalu meminta bantuan teman atau saudaranya dalam memecahkan masalah disoal geomteri.60\% mahasiswa, tugas geometri yang mereka kerjakan selalu dikumpulkan tanpa ada niat untuk memperbaiki jika ada kesalahan. $45 \%$ mahasiswa mengalami kesulitan untuk memecahkan masalah di soal geometri diluar contoh yang ada. $71 \%$ mahasiswa, jika mereka mendapat atau memperoleh nilai geometri yang rendah maka merekan akan lebih giat belajar. $55 \%$ mahasiswa, setiap tugas yang diberikan, jarang memberikan hasil yang baik dan memuaskan. $74 \%$ mahasiswa mencoba sungguh, maka dapat memecahkan masalah di soal geometri yang diberikan.55\% mahasiswa putus asa jika mengerjakan soal geometri yang sulit.55\% mahasiswa merasa setiap tugas yang dikerjakan, kebanyakan hasilnya baik dan memuaskan.55\% mahasiswa merasa geometri adalah mata kuliah yang tidak mereka kuasai.67\% mahasiswa sangat menikmati mata 
kuliah geometri. 59\% mahasiswa tidak pernah berniat mangambil jam atau pelajaran tambahan geometri. 63\% mahasiswa kurang menyukai mata kuliah geometri.55\% mahasiswa selalu dapat memecahkan masalah di soal-soal geometri dengan baik.61\% mahasiswa menyukai mata kuliah geometri.59\% mahasiswa tidak suka bila mendapat tugas geometri. $61 \%$ mahasiswa bisa menyelesaikan tugas geometri tergantung pada teman, dan $41 \%$ mahasiswa mampu mengerjakan soalsoal geometri di atas 5 jam.

Berdasarkan uraian tentang hasil angket DESCA dan angket self concept untuk sebelum dilakukan pendekatan DESCA dan sesudah dilakukan pendekatan DESCA diperoleh bahwa potensi DESCA (dignity, energy, self management, community, awareness) pada mahasiswa mengalami peningkatan. Hal ini dilihat rata-rata hasil angket untuk 31 mahasiswa yaitu 3,56 menjadi 3,72,dan melalui pendekatan DESCA, dapat meningkatan level self concept yang ada dalam diri mahasiswa.

Perubahan dan Penyebabnya Terkait Kemampuan DESCA dan Self-Concept Mahasiswa Baru Prodi Pendidikan Matematika Selama Perkuliahan Geometri.

Untuk data kemampuan DESCA diperoleh dari angket DESCA. Tabel berikut menyajikan kemampuan DESCA yang merupakan rekapitulasi dari tabel total kemampuan DESCA.

Tabel 3. Kemampuan DESCA Perkuliahan II dan III.

\begin{tabular}{lccc}
\hline \multicolumn{1}{c}{ Kemampuan DESCA } & Kulh II & $\begin{array}{c}\text { Kulh } \\
\text { III }\end{array}$ & $\Delta \mathbf{x}$ \\
\hline Dignity (Martabat) & $76 \%$ & $81 \%$ & $5 \%$ \\
\hline Energy (Energi) & $67 \%$ & $69 \%$ & $2 \%$ \\
\hline Self Management ( Manajemen Diri) & $72 \%$ & $72 \%$ & $0 \%$ \\
\hline Community (Komunitas) & $77 \%$ & $81 \%$ & $4 \%$ \\
\hline Awereness (Wawasan) & $63 \%$ & $67 \%$ & $4 \%$ \\
\hline
\end{tabular}

Perubahan yang tertinggi dan memperoleh kenaikan adalah pada martabat sebesar 5\%. Ketidakpercayaan diri pada banyak mahasiswa membuat mereka merasakan bahwa martabat atau diri mereka belum memberikan makna untuk yang lain. Di samping kebuntuan yang ditemukan dalam perkuliahan dapat menyebabkan mereka cenderung pasrah tanpa ada upaya yang realistis untuk membangkitkan semangat, sehingga dapat lebih yakin atas kemampuan yang dimiliki, sedangkan aspek manajen diri tidak memberikan perubahan $(0 \%)$ dapat disebabkan karena mereka merasakan bahwa manajemen diri sesungguhnya tak terjadi pada mereka. Manajemen diri bagi mahasiswa tersebut lebih pada pembiasaan yang tak dapat diukur dan tidak menjadi perhatian.

\section{Simpulan dan Saran}

Posisi tangga pembelajaran aktif mahasiswa baru Prodi Pendidikan Matematikaperkuliahan geometri sebelum pengoptimalan kemamapuan DESCA cenderung pada tangga 


$\begin{array}{llllrr}\text { pembelajaran } & \text { mahasiswa } & \text { yang } & \text { Agustiani, } & \text { Hendrianti. } & \text { (2006). } \\ \text { bertanggung jawab.Aspek DESCA } & \text { Psikologi } & \text { Perkembangan } \\ \text { mahasiswa baru cenderung pada } & \text { Pendekatan Ekologi Kaitannya } \\ \text { perubahan kearah yang lebih baik } & \text { dengan Konsep Diri ran } \\ \text { adalah aspek komunikasi. Kondisi ini } & \text { Penyesuaian } & \text { Diri } & \text { Pada } \\ \text { disebabkan karena mereka merasa } & \text { Remaja.Bandung: PT } & \text { Refika } \\ \text { orang yang masih dalam dunia kampus } & \text { Aditama } & & \end{array}$
jadi masih mencari jati diri, sehingga martabat yang dimiliki dijaga dengan penuh hati-hati.Self concept mahasiswa baru Prodi Pendidikan Matematika perkuliahan geometri pada pertemuan ke 2 dan ke 3 belum menggambarkan konsep diri yang jelas, karena sebagian dari mahasiswa tersebut tidak memiliki

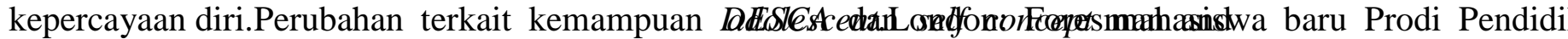
DESCAmahasiswa ada baiknya penelitian dikaji dalam satu semester dan diberikan perlakuan yang variatif. Pengkondisian dilakukan memungkinkan untuk tidak disadari mahasiswa, sehinggga tampak lebih alami.

Bonwell, C.C. (1995). Active Learning: Creating excitement in the classroom. Center forTeaching and Learning, St. Louis College of Pharmacy.

Fuhrmann, B.S. (1990).Adolescence, Company.

Ghufron, M. Nur dan Rini Risnawita S. (2011).Teori- Teori Psikologi. Yogyakarta: AR- Ruzz Media

Sulipan. (2009). Penelitian Deskriptif Analisis Berorientasi Pemecahan

\section{Daftar Pustaka} Masalah.Artikel.Diambil dari http://www.scribd.com/doc/541866 71/ Penelitian-Deskriptif-AnalitisSulipan [23 Maret 2013]. 